[Frontiers in Bioscience 3, d1192-1208, December 1, 1998]

\title{
PAPILLOMAVIRUS VACCINES
}

\section{Margaret F. Duggan-Keen, Michael D. Brown, Simon N. Stacey and Peter L. Stern}

Paterson Institute for Cancer Research, Christie Hospital NHS Trust, Manchester M20 4BX, United Kingdom

Received 7/21/98 Accepted 9/22/98

\section{TABLE OF CONTENTS}

1. Abstract

2. Introduction: Why HPV vaccines?

3. Issues in vaccine design:

3.1. HPV life cycle

3.2. Target antigens for prophylaxis or therapy

3.3. Natural immunity against HPV

4. Candidate vaccines

4.1. Animal models

4.2. Virus like particles (VLPS)

4.3. Proteins

4.4. Peptides

4.5. Viral vectors

4.6. DNA

4.7. Bacterial vectors

4.8. Dendritic cells

5. Vaccine clinical trial parameters

5.1. Evaluation of vaccine clinical efficacy

5.2. Cost and ease of implementation

5.3. Why might HPV vaccines not work?

6. Summary

7. Acknowledgement

8. References

\section{ABSTRACT}

The considerable morbidity and mortality associated with certain human papillomaviruses (HPV) has provided the impetus for HPV vaccine development. The design of such vaccines has evolved from an understanding of the nature of HPV infections and their consequences, together with evaluation of the efficacy of different approaches to vaccination in animal models. These studies have culminated in the production of several different vaccine preparations which are currently undergoing Phase I and II clinical trials. The justification for the widespread implementation of prophylactic HPV vaccines will depend on the outcome of larger scale studies of vaccine efficacy that take into account the epidemiology of HPV infections and associated disease. The usefulness of therapeutic HPV vaccines will require evidence that they can substantially augment or substitute for the effectiveness of currently available treatments.

\section{INTRODUCTION: WHY HPV VACCINES?}

Papillomaviruses (genus Papillomavirus of the Papovaviridae family) are associated with cutaneous or mucosal benign and malignant lesions in many species including humans. Over 95 types of human papillomaviruses (HPV) have been classified on the basis of DNA sequence homology, with the latter correlating with biological behavior and tissue tropism (1). For example, HPV 6 or 11 are found in benign anogenital warts which although not life threatening may be refractory to conventional treatment and frequently reoccur. These HPV types also cause recurrent laryngeal papillomas in young children, with frequent laser surgical ablation necessary to maintain an open airway (2). This type of HPV infection can be associated with considerable morbidity but rarely with malignancy. Immunological approaches to treatment of HPV associated benign lesions would clearly be very useful.

The evidence for the association of certain HPV types with the etiology of cervical neoplasia is firmly established, with HPV detected in up to $98 \%$ of all cervical cancers (3-5). Of the fifteen HPV types isolated from cervical carcinomas, HPV16 and HPV18 are most frequently detected. Cervical cancer is the second most common cause of cancer related death in women, and in some developing countries, it accounts for the highest cancer mortality (6). This malignancy is preceded by dysplastic precursor lesions which can be histologically classified (cervical intraepithelial neoplasia, CINI-III) on the basis of progressive cellular atypia and disturbed epithelial architecture. HPV prevalence rates of up to $70 \%$ in women with CINI and 75-100\% for CINII/III have been reported (7-9). Cervical screening programs exist to reduce incidence, morbidity and mortality from cervical cancer, and they have had a measurable effect in some Western countries (10-13). However such programs will not eliminate HPV, due to the occurrence of asymptomatic infection, and they are also costly and difficult to implement in developing countries. A strategy for management of cervical neoplasia world-wide could be the development of prophylactic and/or therapeutic HPV vaccines. 
This review will discuss the natural history of HPV infection, viral immunity and the clinical course of resultant disease as the background to the effective design and use of HPV vaccines for protection or therapy.

\section{VACCINE DESIGN: CHOICE OF TARGET ANTIGENS}

\subsection{HPV life cycle}

Studies of the natural history of HPV infection provide information as to when, where and in what quantities different viral genes are expressed. This, together with a knowledge of how viral protein expression is altered in the process of malignant transformation, can help to determine the most appropriate antigens for vaccination.

HPVs are icosehedral non-enveloped viruses containing double stranded circular DNA molecules of approximately $8 \mathrm{~Kb}$; the genome contains eight open reading frames (ORF) and a non-coding region containing transcription regulatory sequences and the origin of replication. The early $(\mathrm{E})$ ORFs encode proteins involved in DNA replication, transcription and cellular transformation while two ORFs in the late region encode the capsid proteins L1 and L2.

HPVs are exclusively epitheliotropic, and their infectious cycle is dependent on the life history of the epithelium, where cells migrate from the basal layer, differentiating as they progress to be exfoliated from the surface and replaced by cells from below. Primary HPV infection is thought to occur in either the basal or parabasal cell, and subsequent viral protein expression correlates with the differentiation stages in the spinous layers (reviewed in 14). Following penetration of the epithelium by an as yet unknown mechanism, the virus particles composed of capsids formed from the major (L1) and minor (L2) late proteins interact with surface molecules of the target cell and facilitate entry of the viral DNA (15); the alpha (6) integrin has been identified as a candidate receptor for papillomaviruses (16). Initially, the immediate early proteins E1, E2 and E5 can be detected. The E1 and E2 ORFs each encode DNA binding proteins; their products are required to maintain a stable viral episome. The E1 protein is a DNA-dependent ATPase and a DNA helicase required for both initiation and elongation of DNA synthesis (17). The functions of E2 include the positive and negative regulation of viral gene expression through specific interaction with the early promoter. In the lower spinous layers, E6 and E7 are expressed in addition to the other early proteins; they are involved in regulating cell proliferation, interfering with the host cell cycle control mechanisms to activate cellular DNA synthesis which seems to be essential for viral vegetative DNA replication. In the upper spinous layers, vegetative DNA amplification and virus assembly occurs with expression of L1 and L2 proteins. Although encoded within the early region, E4 protein expression is also largely restricted to the upper spinous layers; the precise role of E4 is unknown, but it interacts with the keratin intermediate filaments in cultured epithelial cells (reviewed in 18). Mature virions are released from exfoliating cells.

In the HPV types associated with malignant transformation, it is clear that E6 and E7 are the predominant transforming proteins, although E5 can also show oncogenic potential (19). The major mechanism by which oncogenic HPV- E6 and -E7 contribute to the development of cervical cancers is by functional interaction with the cell proteins p 53 and retinoblastoma $(\mathrm{Rb})$ respectively; these proteins play a pivotal role in the negative regulation of growth (reviewed in 20). E6 from oncogenic HPVs bind to p53 with high affinity, resulting in loss of p53-dependent functions including G1 arrest and apoptosis. The consequence of binding of E7 to $\mathrm{Rb}$ is to prevent Rb-binding and sequestration of E2-F transcription factors leading to disruption of cell cycle control.

In initial infection, HPV is present as an episome, but in the majority of more advanced lesions and invasive tumors HPV is integrated into the host genome $(21,22)$. E6-E7 transcripts from integrated HPV genomes have increased stability compared to episomally derived viral mRNA, and there is increased expression in more severe lesions and cancers (23). This may result from disruption of the E2 gene during integration. Following integration, viral particles can no longer be produced, but continued E6 and E7 activity prolongs the cell cycle, leading to the loss of effective DNA repair mechanisms. This provides the opportunity for the accumulation of genetic changes in a multistep process that can result in the development of cancer. Thus, numerical and structural chromosomal changes in cervical cancer are common, and allelic losses have been observed in many different chromosomal regions (24-26).

\subsection{Target antigens for prophylaxis or therapy}

Both prophylactic and therapeutic vaccines could have a role in combating HPV-associated disease. A prophylactic vaccine would aim to prevent HPV infection by generating an effective immune response at the site and time of infection, thereby inhibiting the establishment of long-term infection and re-infection. Such a vaccine would most benefit individuals at greatest risk of exposure to HPV. For HPV types associated with cervical neoplasia, a suitable population could be young women at the onset of sexual activity, since it is in this group that the highest prevalence of HPV infection has been measured. Therapeutic vaccination on the other hand would be directed at the elimination of established infection, both in benign and malignant disease. Initially, therapeutic vaccination would be likely to be administered as an adjuvant to conventional treatment.

Although targets responsible for immune regression of HPV-induced lesions have not been clearly identified, the available data suggest that HPV viral proteins can be immunogenic, and taking into account the HPV life cycle, the most suitable candidates for prophylactic and therapeutic vaccines are likely to be HPV L1/L2 or E6/E7 genes and their products respectively. Relatively little is known about the immunogenicity of other viral products in humans, however E2 could provide a suitable target for therapeutic intervention in low grade dysplasias.

A prophylactic immunogen should be in a conformation that induces neutralizing antibodies that recognize, bind to and prevent the spread of virus particles produced during natural infection. However, cell-mediated surveillance of virally-infected cells would also be important in the ultimate resolution of the infection. The lack of an in vitro propagation system for the production of HPV virions has hampered the availability of suitable material for prophylactic vaccine development. The discovery that expression of the major capsid protein L1 in eukaryotic cells resulted in self-assembly into viruslike particles (VLPs) was a major advance $(27,28)$. VLPs are morphologically indistinguishable from native virions, and 
conformational epitopes required for the induction of neutralizing antibodies are preserved (28).

Virus particles are not made in cervical lesions and tumors where HPV integration has occurred, thus the induction of immunity to HPV late proteins could not be effective in eliminating such lesions. However, in malignant lesions, there is constitutive protein expression of HPV E6/E7 antigens, making them attractive targets for therapeutic vaccines. In addition, since E6 and E7 are required for continued tumor growth, the problem of tumor heterogeneity encountered for other cancer vaccines (where tumor-associated antigens may cease to be expressed), may not be an issue in the design of HPV therapeutic vaccines.

\subsection{Natural immunity against HPV}

The natural component of viral clearance in HPV infections is not known, but the increased frequency of HPVassociated lesions in individuals with depressed cell-mediated immunity suggests that the immune response normally has a role in controlling HPV infection (29-31). Most viral infections are eliminated by cell-mediated responses, and humoral immunodeficiency does not result in an increase in HPV lesions, making it unlikely that antibodies alone are responsible for viral clearance (32). The majority of apparently immunocompetent individuals infected with HPV are able to clear the infection with no further consequences, but persistent infection is correlated with progression of cervical disease $(33,34)$. However, even where there is cervical dysplasia in addition to HPV infection, lesions often regress spontaneously, particularly in younger individuals and where the dysplasia is mild (reviewed in 35). Spontaneous regression of genital warts is also common.

It is not understood why HPV infections persist in some healthy individuals. The underlying cause may be the same as that responsible for the development of lesions in immunosuppressed patients (i.e. a failure to develop viral immunity), due to host immunological and/or genetic factors. Recently, a p53 polymorphism has been identified that is more susceptible to HPV E6-mediated degradation, conferring a significant risk factor for the development of HPV-associated cancers (36). Alternatively, some infections may result in escape from the normally effective immunity. For example, cutaneous warts may persist because they do not present any 'danger' to the host (see 37) and then can suddenly disappear, presumably because they become visible to the immune system. For some progressive cervical lesions, the immune system may not be triggered until after HPV integration and other cellular events contributing to malignant transformation have occurred, compromising the relevance of such immunity in resolving the malignant lesion.

Antigen presenting cells (APCs) are critical for the induction of all $\mathrm{T}$ cell-dependent immune responses. Dendritic cells are the most potent APCs, with a unique capacity to stimulate naïve $\mathrm{T}$ helper and cytotoxic cells and initiate a primary immune response. $\mathrm{T}$ helper cells stimulate different types of immunity, depending on the pattern of cytokines that they secrete, thereby defining Type 1 and Type 2 responses (38). Type $1 \mathrm{~T}$ helper (Th1) cells secrete gamma -interferon (IFN), tumor necrosis factor and interleukin-2 (IL-2) important for the generation of delayed type hypersensitivity (DTH) responses and cytotoxic T cells (CTLs) whereas Type $2 \mathrm{~T}$ helper (Th2) cells principally support antibody responses (particularly IgG1, IgE and IgA) through IL-4 and IL-5 secretion. $\mathrm{T}$ helper cells also differ in their response to cytokines, for example IL-12 promotes the development of Th1 cells whereas Th2 cells are responsive to IL-10. However, this classification is not absolute, particularly in humans, and most successful immune responses probably require coordination of both Type 1 and Type 2 responses $(39,40)$. Interestingly, antigen-stimulated Th cells can also influence the direction of an immune response through their interaction with CD40 expressed on dendritic cells; dendritic cells thus activated can then directly stimulate CTLs (41-43). It is therefore clear that the primary events in antigen presentation are critical in determining the outcome and putative efficacy of an immune response.

HPV infections do not spread systemically, and natural anti-HPV immunity presumably has to be induced at mucosal sites. The common mucosal immune system is separate from the systemic immune response, with a bias towards $\mathrm{T}$ helper responses important for the induction of mucosal $\operatorname{IgA}$ responses although mucosal immunization can induce systemic antibodies. Immune responses in the female genital tract also have to be effective in the face of an environment which fluctuates with the menstrual cycle; hormonal levels can affect CTL activity, and local cytokine conditions will also influence the type of immune response generated (44). Many studies have looked for immune responses to HPV in patients with overt disease as well as in individuals with asymptomatic infection, but the systemic responses observed may not necessarily be representative of the type or efficacy of immunity at the site of HPV lesions, although they are relevant to locally invasive and disseminated disease in cancer patients. The pattern of immune responses in individuals with regressing lesions and those where HPV infection resolves without any overt lesion are most likely to identify the critical components (what type of response against which viral antigens) in the natural control of HPV infection. In addition, a knowledge of the immune response to HPV in patients with persistent/progressing lesions or malignant disease is also important in selecting the viral antigens most likely to induce successful therapeutic immunity and in monitoring vaccine efficacy.

Regressing genital warts are characterized by increased infiltration of activated CD4+ T cells and macrophages (45). Inflammatory Th1 cells, macrophages and NK cells together with increased HLA class I and II expression are seen in genital wart biopsies from patients responding to treatment with IFN gamma and IFN alpha 2a (46). There are few studies of $\mathrm{T}$ cell function at the site of genital warts, however in a study of wart infiltrating lymphocytes, specific proliferative responses to HPV-6/11 L1 peptides were evident in the majority of patients whereas proliferation in response to HPV6/11-E7 protein and/or peptide only occurred in $15 \%$ of patients. Proliferative responses to E7 were more frequently detected in peripheral blood lymphocytes, so it is not clear whether they are relevant to the disease course (47).

In the cervix, the frequency of Langerhans cells (epithelial dendritic cells) is inversely correlated with disease severity (48-51). A lack of these professional antigen presenting cells may result in no immune response or the initiation of an inappropriate one $(52,53)$. However, tumor infiltrating lymphocytes are detectable in cervical cancer, and a recent 
study detected tumor and local lymph node -derived CTLs with specificity for HPV16 -E7 (54-57).

It might be expected that effective $\mathrm{T}$ helper responses to L1 would emerge at the early stages of infection, when late protein synthesis occurs as part of the production of infectious virions. But L1 responses might be sustained even in progressive CIN lesions because of continued virus production separate from the transformed cells with integrated viral DNA. $\mathrm{T}$ helper responses to L1 presented as peptides or as VLPs have been detected in vitro by proliferation and IL-2 release assays respectively in CIN patients as well as controls, but responses are not found more frequently in patients with low grade lesions $(58,59)$; there also is a trend towards a decrease in Th1 type responses with increasing grade of dysplastic lesion (60).

Serological assays using virus-like particles (VLPs) indicate that a high proportion of individuals exposed to HPV with and without cervical lesions develop systemic antibodies to L1 and/or L2 (61-68). In addition, IgA antibodies against capsid proteins are found in cervical secretions (69). These Thdependent antibody responses do not predict HPV clearance, but not all conformational-dependent antibodies are necessarily neutralizing, therefore the pattern of L1 antibodies detected may not correlate with efficacy of HPV elimination (70). Neutralizing antibodies may be an effective way of preventing viral infection and spread, but cell-mediated surveillance of virally infected cells may also be important in the ultimate resolution of infection and disease. Perhaps not surprisingly, HPV type-specific L1 antibodies are found less frequently in patients with invasive cancer, where HPV is usually integrated, and the ability to make viral particles is lost (62).

Th responses to HPV16 E7 are found in CIN patients but are less frequently observed in cervical cancer patients, possibly reflecting a failure of correct E7 presentation for the maintenance of E7-specific $T$ cells, or genetic unresponsiveness(71-78). There is no clear relationship between E7 responses and disease severity or outcome in CIN patients. For example, in patients treated for CIN, T cell proliferation to HPV16 E6 and E7 peptides was found to be predictive for the subsequent clearance of HPV DNA (75). However, it is possible that the HPV-specific responses in these patients were generated as a consequence of taking the biopsy, creating an adjuvant effect on maintaining viral clearance. This would be compatible with the observation that in patients followed longitudinally without intervention, there was an association of Th responses (measured by IL-2 release) with viral persistence and high grade premalignant lesions whereas in patients who cleared their infections, high responses detected around the time of viral clearance subsequently declined (73). The observed cellular immunity in patients with resolving or persistent lesions may be reconciled by the common factor of antigen load reaching a threshold, either as part of the natural resolution of the disease or its progression.

There is little evidence for increased E7 antibody production in CIN patients compared to controls $(79,80)$. In a study of CIN patients followed longitudinally, IgG responses were significantly higher and found most frequently (29\%) in CIN patients with cleared HPV16 infection, but they were also present in $11 \%$ and $14 \%$ of patients with persistent or fluctuating HPV 16 infection (81). Serological responses to HPV E7 are consistently found in $25-50 \%$ of cervical cancer patients (reviewed by 82 ). However, it is difficult to imagine how such antibodies could have a role in eliminating established HPV infection. It seems more likely that they develop as a bystander effect of prolonged exposure to HPV and increasing viral load.

Th1 responses to E7 are likely to be relevant to the generation of E7-specific CTLs which would be predicted to be an effective mechanism for the elimination of cervical lesions, providing other factors (local cytokines, expression of HLA and accessory molecules) were optimal. CTLs are generated following the presentation of immunogenic peptides by HLA class I antigens on professional antigen presenting cells such as dendritic cells, and usually require Th1 help. Candidate peptide epitopes from HPV16 E6 and E7 which could be presented by the most common HLA-A alleles have been identified; some of these elicit peptide-specific CTLs which have activity against HLA-matched tumor cells. However, the frequency of individuals where CTLs can be detected following in vitro stimulation with such peptides is low (83-87). There may be a paucity of circulating HPV-specific CTLs in peripheral blood; a comparison of peptide-specific responses in peripheral blood, local lymph node and tumor infiltrating lymphocytes from cancer patients indicated that HPV-specific CTLs were more abundant at the site of antigen exposure (57). The CTL detection methodology is limited by HLA and peptide whereas in vitro restimulation with adenovirus recombinants expressing HPV E6 and E7 allows responses to reflect the presentation of multiple naturally processed peptides in the context of the host HLA genotype. Using this method, HPV-specific CTL responses in the peripheral blood of $6 / 10$ CIN III patients were detected, but no responses were seen in healthy controls, suggesting the presence of naturally occurring HPV-specific memory CTLs (88). To date, no studies of CTL responses in relation to disease course have been reported, however CTL killing of HPV-vaccinia targets elicited in vitro by stimulation with E6 and E7 fusion proteins were more frequently detected in HPV16 positive patients that had no evidence of disease compared to those with CIN (89).

In summary, there is evidence that HPV infection and associated malignancy can induce humoral and cellular immunity to capsid and oncogene viral proteins but the role of such responses in resolution rather than as a consequence of the disease is not clear.

\section{CANDIDATE VACCINES}

\subsection{Animal models}

Different candidate HPV vaccines have been developed and their immunogenicity and, where possible, efficacy in protection or therapy evaluated in different animal models. Some studies have immunized mice directly, for example HPV16-E6 or E7-transfected cell lines induced CTLmediated tumor rejection $(90,91)$. Other models have attempted to mimic natural viral infection, for example using a transplantation technique in mice with a keratinocyte cell line expressing HPV16 E6 or E7 that results in the formation of a differentiated epithelium (92). DTH responses were elicited in response to challenge with E6 and E7 in this model, however immunological unresponsiveness occurred with low dose priming, indicating that the dose used for human vaccines may be critical $(93,94)$. Transgenic models have been used to test concepts of tolerance or anergy with respect to HPV proteins.

Thus, transgenic mice with HPV 16 expression restricted to epithelium in adult life are not impaired in their ability to mount 
an immune response to E7 (95). However, in transgenic mice expressing HPV proteins neonatally, there is evidence both for immunological tolerance and ignorance $(96,97)$.

In addition to the study of HPV in mouse models, vaccines have been developed for papillomavirus infections which occur naturally in other mammalian species. The Shope papillomavirus (CRPV) affects domestic and cottontail rabbits, where cutaneous lesions can spontaneously regress, or persist, with progression to tumors. Canine oral papillomavirus (COPV) induces benign lesions at mucosal (although not genital) sites. There are several bovine papillomaviruses (BPV), including cutaneous (BPV1 and BPV2) and mucosal (BPV4) viratypes; BPV4 infection can result in malignancy, however the BPV genome is not retained during malignant conversion (98). Although neither the animal papillomaviruses nor mouse models completely mimic the human virus-host interaction, they do provide the necessary background for human vaccine development.

\subsection{Virus-like particles (VLPs)}

The ability of VLPs to mimic the conformation of natural HPV virions make them attractive prophylactic vaccine candidates. VLPs have now been produced for all the major HPV types associated with human disease, in a variety of expression systems including yeast, insect cells and E.coli (28, 99-102). An additional advantage of VLPs designed for prophylactic vaccines is that they do not contain the viral genome and therefore uninfected individuals would not be exposed to viral oncogenes. A Phase I clinical trial to evaluate HPV-11 L1 VLPs (MEDI-501) in healthy volunteers has been initiated at the University of Rochester Medical Centre (USA) in association with MedImmune Inc, and trials with HPV-16 and -18 VLPs are planned.

The efficacy of VLPs in protecting from viral challenge has been demonstrated in several animal models. Immunization of rabbits with CRPV VLPs in alum or Freund's adjuvant can protect against challenge $(103,104)$. High titre antibodies are made, and protection is transferable with serum. Protection can be long-term although neutralizing antibody titres drop 100-fold over a year (105). In a canine model, intradermal inoculation into the foot pad induced circulating antibodies against COPV, and animals became completely resistant to oral challenge with wart homogenate. As in the CRPV model, protection could be passively transferred with serum (106). Intra-muscular administration of BPV4 L1 or L1/L2 VLPs protect cattle from mucosal challenge (107). Systemic immunization with HPV-11 VLPs in monkeys elicits significant levels of neutralizing antibodies in cervico-vaginal secretions suggesting that it may not be necessary to directly immunize at mucosal sites to elicit mucosal antibodies (108).

Although considered mainly for their ability to induce neutralizing antibodies, VLPs can also induce cell-mediated immunity; proliferative Th1 responses develop in mice immunized with HPV16-L1 VLPs (109). Chimeric VLPs have been designed which incorporate relevant early region proteins in addition to the late proteins (110). In mice, VLPs containing HPV16 E7 confer anti-tumor immunity, and strong CTL responses are elicited by hybrid BPV1-L1/HPV16-E7 VLPs $(111,112)$. Thus, peptides derived from VLPs can reach the HLA class I pathway of presentation, allowing for CTL induction and raising the possibility that chimeric VLPs might provide a one-agent vaccine suitable for combined prophylaxis and therapy.

\subsection{Proteins}

The conformation of proteins engineered for vaccines might be expected to influence the generation of effective antibody responses whereas the induction of $\mathrm{T}$ cell responses does not depend on protein conformation. Immunization with a CRPV L1 fusion protein elicited neutralising antibodies and protected rabbits from papilloma development, providing the full-length nondenatured product was used; animals immunized with L1 subfragments containing the major epitope failed to induce neutralizing antibodies (113, 114). In cattle, BPV late proteins also confer protection, but for BPV4-L2, the $\mathrm{N}$ terminus is sufficient to prevent mucosal infection and elicit neutralizing antibodies (115-117).

Early proteins also induce immunity in rabbits; vaccination of CRPV E1 and E2 with or without adjuvant induces regression of virus-induced papillomas (118). In the course of natural papilloma development, more animals with regressing papillomas have antibodies to CRPV-E2 than those with persisting papillomas, whereas for other structural proteins the two groups do not differ. There is also a bias towards proliferative responses to E2 in regressors whereas E6 and E7 responses were infrequent in both groups, suggesting that induction of anti-E2 immunity is important for resolution of CRPV-induced lesions (119).

If proteins are to be used as therapeutic vaccines, it will be important for them to be processed and presented by HLA molecules. The administration of soluble protein is thought to direct peptides to the HLA class II pathway, thus eliciting helper rather than cytotoxic responses, however, in mice, there is evidence for CTL generation using HPV16-E7 protein in adjuvant (MF59); the fine specificity of these CTLs was similar to that generated by vaccinia encoding HPV16-E7 (120). Murine CTL responses to HPV16-E7 can also be augmented by heat aggregation, and immunization of mice with immunostimulating complexes (ISCOMS) containing HPV11 E6 or E7 fusion proteins can induce CTLs $(121,122)$.

In the Phase IIa clinical trial of genital warts, TA-GW vaccine, a fusion protein vaccine consisting of HPV6 L2E7 adjuvanted with Alhydrogel was administered intramuscularly.

IgG antibodies were detected in all patients, and $85 \%$ of patients made antigen-specific $\mathrm{T}$ cell proliferative responses. Encouraging clinical responses were observed and randomized double blind controlled trials will allow the relationship between efficacy and immune correlates of regression to be examined (123). In Australia, a glutathione -S-transferase-HPV16-E7 fusion protein has been administered with Algammulin adjuvant to five patients with late stage cervical cancer; all patients made HPV 16-E7 antibodies, and proliferative T cells responses to E7 protein and peptide were detectable in two of three patients that were evaluated (reported by 124).

\subsection{Peptides}

Peptides are attractive candidates for vaccines as they are cheap to produce, and regulatory issues are minimal. Disadvantages are their very short half life in vivo, and the requirement to identify relevant peptide sequences compatible with individual host HLA genotype. The majority of human studies of immune responses to peptides have been to HLA-A2- 
binding peptides. Candidate HLA-binding peptides can be predicted from computer analysis of peptide-binding motifs and binding assays generally correlate well but not completely with such predictions $(125,126)$.

HPV16-E6 and -E7 proteins contain epitopes which bind to mouse MHC class I alleles and can induce CTLs in vitro, however peptides not predicted from binding studies to be immunogenic can be CTL epitopes, and conversely, binding peptides may not be naturally processed $(127,128)$. However, mice immunized with the $\mathrm{H}-2^{\mathrm{b}}$-binding HPV16-E7 peptide RAHYNIVTF are protected from challenge with HPV16transformed tumor cells: the specific CTLs generated could also eradicate established tumors $(129,130)$.

Different strategies have been used to try and enhance the immunogenicity of peptides. Altering an HPV 16 E6 peptide to augment $\mathrm{H} 2$ binding has been effective in enhancing CTL generation by peptides; perhaps surprisingly, CTLs raised against the engineered peptide were effective in killing a cell line transfected with the native E6 peptide (131). Anti-HPV16-E7 antibodies can be elicited in mice by polymerised peptides containing $\mathrm{B}$ and $\mathrm{T}$ cell epitopes; this response is enhanced by incorporating the peptides into ISCOMS (132). Peptide immunogenicity in mice is also enhanced by conjugation to the immunostimulatory TraT protein from E.coli (133). In clinical trials of peptide-based vaccination in melanoma, the inclusion of GM-CSF in the immunization protocol markedly increases immunogenicity (CTL detection and DTH responses) to intradermally injected peptides (134).

It is clear that peptide-based vaccines can be protective against HPV tumors in mice, however mice have different $\mathrm{T}$ cell repertoires to humans, therefore epitopes defined as protective or dominant or subdominant in mice may be irrelevant for the choice of peptides for human vaccination. However, HLA-A*0201 transgenic mice have been used to confirm the immunogenicity of peptide motifs that could also induce CTLs in healthy human donors (85). Murine studies have indicated that some peptides might induce functional deletion of CTLs in humans. For example, in a murine model of human adenovirus type 5 early region 1A-induced (Ad5E1A) tumors, subcutaneous vaccination with synthetic Ad5E1A peptide resulted in enhanced tumor outgrowth whereas the same peptide conferred protection when delivered on dendritic cells $(135,136)$. Patient recruitment to peptide-based vaccines are always limited by HLA genotype, and there is no information to date as to the immunogenicity of HLA-A2-binding HPV epitopes compared to the immunogenicity of epitopes which bind to other HLA class I (-A and -B) alleles. The existence of HPV variants is also relevant for the selection of HPV peptides (137139). Nevertheless, up to $50 \%$ of Caucasians carry the HLA-A2 allele, and a Phase I/II peptide-based clinical trial of the HLAA*0201 binding HPV16-E7 peptides is underway at the University of Leiden in the Netherlands. Two HLA-A*0201restricted HPV 16 E7-encoded peptides are administered together with a T-helper epitope in an adjuvant. Other peptidebase clinical trials are also in progress in at the Norris Cancer Centre, University of California, at the NCI and at the NCI/Navy Medical Oncology Branch (140).

\subsection{Viral vectors}

The advantage of viral vectors for the delivery of vaccines is that viral protein synthesis within infected cells will generate an array of peptides for presentation through the HLA class I pathway. As in natural infection, the specific viral peptides that result in CTL generation will depend on the host T cell repertoire and HLA genotype, and a knowledge of which peptides are being presented is not required. Therefore patients would be eligible for vaccination irrespective of their HLA genotype, and more than one HPV type could be incorporated into a vaccine. Vaccinia is a convenient vehicle because it has been extensively used in the eradication of smallpox (141). In addition, vaccinia is very amenable to gene manipulation and it has a large capacity for inserted DNA. The ability of recombinant vaccinia viruses encoding foreign antigens (rVV) to generate CTLs in animal models and in humans is established (142-144). Studies in mice indicate that CTLs can be generated using rVV expressing HPV16 L1, however using a late promoter, only antibody responses were induced (145). T cell proliferative, cytotoxic and antibody responses could also be induced in mice using rVV expressing HPV16 E6 under an early promoter (146). rVV encoding HPV16-E7 is also effective in inducing specific CTLs in mice (120). Optimal CTL generation requires $\mathrm{T}$ cell help, and immunization of mice with $\mathrm{rVV}$ containing a chimera of HPV16-E7 together with lysosomeassociated membrane protein to enhance MHC class II processing protected $80 \%$ of mice from challenge with an HPV16-E6 and -E7 transformed cell line. Immunization with rVV encoding HPV16-E7 alone led to a delay in tumor formation but tumors appeared within three weeks. In addition, the chimeric vaccinia was effective in curing mice with small established tumors (147).

A Phase I/II trial in which eight late stage cervical cancer patients were immunized once by dermal scarification with an rVV expressing E6 and E7 from HPV types 16 and 18 (TA-HPV) has already been completed. There were no significant clinical side effects, and all patients developed IgG antibodies to vaccinia, indicating a successful vaccine 'take'. An HPV-18 E6/E7 specific CTL response was detected at nine weeks post-vaccination in one of three patients; this response was no longer evident 14 and 20 weeks post-vaccination. The tumor from this patient was HPV16 positive, suggesting that the CTL response was a result of immunization with TA-HPV; this patient experienced remission of her disease and was tumor free 15 months post-vaccination (148). TA-HPV is now at the Phase II stage in a multicenter EORTC trial where it is being administered to cervical cancer patients with stage $1 \mathrm{~B}$ and $2 \mathrm{~A}$ disease receiving standard surgery or radiotherapy; patients receive two immunizations; serological and immune responses to HPV will be assessed before and at several time points following immunization and treatment. A Phase I/II trial of TA-HPV has also been opened for CIN III patients in Wales, and at the National Cancer Institute for patients with advanced or recurrent disease (140).

Other viral vectors which might have a role in HPV vaccines include the modified vaccinia virus Ankara (MVA), and recombinant avipox. MVA is a highly attenuated strain of vaccinia which replicates inefficiently in human cells, making it unlikely to cause the complications that can occur when immunocompromised individuals are immunized with replication competent vaccinia. In a murine tumor model, recombinant MVA expressing beta-galactosidase conferred protection which was therapeutically effective by adoptive transfer (149). Avipox can infect mammalian cells and express early genes, but it cannot 
replicate. A recombinant fowlpox expressing beta-galactosidase has been shown to confer protection from challenge in mice, and to prolong survival of mice bearing established 3-day metastases (150). In humans, a recombinant canarypox-rabies vaccine elicited neutralizing antibodies above the level normally considered to be protective and a recent trial with an avipox HIV-env recombinant reported neutralizing antibodies in $90 \%$ of vaccinees and env-specific CTL in $40 \%$ of vaccinees $(151,152)$.

\subsection{DNA}

DNA vaccination involves the direct introduction of DNA encoding the antigen of interest into host cells where the antigen can then be synthesized. There is now considerable evidence that DNA vaccines can be effective, and they have some advantages over other vaccine preparations $(153,154)$. These include the ability to induce both CTL and antibody responses, relative ease of preparation, no adjuvant requirement, and stability. In addition, the route of administration can be manipulated to influence the type of immune response generated, with saline injection favoring Th1 responses and Th2 responses predominating after gene gun delivery $(155,156)$. Initial safety tests for some DNA vaccines have been completed, and Phase I clinical trials of vaccines for HIV, influenza, hepatitis B and malaria initiated.

Studies of papillomavirus DNA vaccines have so far been confined to the CRPV model, where delivery of CRPV L1 induces antibody responses that can confer protection from tumor challenge (157-159).

\subsection{Bacterial vectors}

Bacteria engineered to express HPV antigens would provide a source of protein for the stimulation of $\mathrm{T}$ cells and antibody induction, however it would be advantageous to target these responses to mucosal sites. For example, Salmonella typhimurium is tropic for gut mucosa, and can elicit humoral, secretory and cell-mediated responses. Two studies have used attenuated strains of live recombinant Salmonella typhimurium engineered to express HPV16-E7 and/or -E6 protein sequences, and successfully induced HPV16-specific immune responses in mice $(160,161)$. In the latter study, IgA responses were detected in the intestine of orally immunized mice. A Salmonella vaccine carrying the HPV16 L1 construct results in the assembly of L1 into VLPs, and a double nasal immunization resulted in systemic and mucosal neutralizing antibody (162).

The ability of Listeria monocytogenes to enter the cytosol of host cells has been exploited for the induction of longterm immunological memory and CD8+-mediated protective immunity against heterologous proteins (163). Recombinant Listeria monocytogenes expressing CRPV E1 protected outbred rabbits from challenge with CRPV or viral DNA, inducing complete regression of tumors with latent DNA being undetectable 4.5 months post regression. Papilloma regression correlated with an in vitro E1-specific proliferative response in the peripheral blood (164).

Another strategy is to use commensal bacteria of the genital tract as vectors, with the aim of maximizing the longevity of HPV protein expression within the mucosal environment. Intravaginal immunization of mice and monkeys with the human commensal Streptococcus gordonii engineered to express HPV16-E7 induces local and systemic immune responses (165, 166).

\subsection{Dendritic cells}

Dendritic cells are potent antigen presenting cells with a unique capacity to stimulate naive $\mathrm{T}$ cells and initiate a primary immune response. Dendritic cells are scarce in peripheral blood, with no lineage-specific surface markers, however recent success in the expansion of dendritic cells ex vivo and their application to other immunotherapeutic trials of cancer make them a feasible route of HPV vaccine administration (167-169). Dendritic cells can be loaded successfully with antigens in different forms, including peptides, protein, DNA, tumor extracts and viral vectors. Using human dendritic cells pulsed with HLA-A2 peptides from HPV11-E6 and -E7 or from HPV16-E7, it is possible to generate CTL responses from some normal donors in vitro $(57,122)$. Mice that received dendritic cells pulsed with HPV16 E7 peptide were protected from tumor challenge and perhaps more importantly were able to eradicate existing tumors of up to $1 \mathrm{~cm}^{3}(170,171)$. In mice, dendritic cells pulsed with HPV16 E7 protein elicited E7-specific CTL responses in vivo with the same efficiency as protein delivered in incomplete Freund=s adjuvant, and both immunogens were associated with tumor protection. Using the same protocol, no protective responses were detected with HPV-16 E6 protein (172) . Immunization with dendritic cells loaded with HPV-E7-encoding plasmid by particle-mediated gene transfer conferred protective anti-tumor immunity in mice (173).

\section{VACCINE CLINICAL TRIAL PARAMETERS}

\subsection{Evaluation of vaccine efficacy}

The clinical trials of HPV vaccines currently in progress or recently completed involve relatively small numbers of patients, and are primarily aimed at assessing vaccine safety and immune responses to HPV. The evaluation of vaccine efficacy will necessitate the recruitment of larger cohorts of patients, and the design of suitable trial endpoints. The appropriate study size and choice of trial endpoint will depend on the nature of the vaccine under evaluation and the cohort of individuals chosen for study. For example, in prophylactic vaccination, an endpoint of HPV infection will require a shorter study time and fewer recruits than an endpoint of detectable lesions (an endpoint of cervical cancer would be impractical!). However, even an endpoint of HPV infection might not be feasible if for example the lag period between immunization and likely exposure to infection/development of disease was several years, It has been calculated that it takes 13.1 years to develop cervical cancer from normal cytology, and the time between initial infection and development of CIN-III is at least six years $(174,175)$. In addition, the prevalence of HPV infection is agedependent $(176,177) ; 20 \%$ of women aged $20-25$ were found to be HPV positive, compared to less than $6 \%$ in those aged more than 30. The prevalence of HPV types associated with cervical cancer decreased from $10 \%$ for women aged between 20 and 35 to $4 \%$ in women of more than 30 . Regression of CIN is also age dependent, with $84 \%$ of premalignant lesions estimated to regress in women less than 34 years, compared to $40 \%$ regression in women aged more than 34 (178). Therefore, the age at which cohorts are recruited for vaccination and subsequently tested is important.

For therapeutic vaccines in CIN and cancer patients, it is likely that vaccines would serve as an adjuvant treatment. Efficacy may be measured in terms of disease recurrence and patient survival, however it should be remembered that the mainline treatment will have the major effect. The overall five 
year survival for cervical cancer patients receiving conventional treatment ranges from $76 \%$ in stage I patients to $7 \%$ in stage 4 patients (179). Thus, the number of early stage patients that would have to be recruited to make a trial powerful enough to detect an effect of vaccination on the frequency of relapse would be proportionally greater than a trial involving late stage patients. Therapeutic vaccine trials for CIN patients would have to be even larger, since the recurrence rate in treated patients is extremely low $(180,181)$. For therapeutic vaccines against HPVs that induce genital warts, however, reduction in the frequency of genital warts could be evaluated more rapidly.

It is clear that measuring HPV vaccine efficacy by disease endpoint, at least for CIN is complex. Relevant immunological assays can also be used to monitor whether an immune response to vaccination has been generated, although it is less easy to determine whether such responses are responsible for disease control. In addition, for therapeutic vaccines, the possible consequences of the mainline treatment on HPV immunity in the absence of immunization has to be taken into account. Although the best chance of detecting an immune response to HPV would be by examining lymphocytes from the genital tract or draining lymph nodes, practical constraints mean that measurements are likely to be confined to peripheral blood.

Evaluation of the significance of antibodies produced in response to vaccination will require the application of a suitable neutralization assay, since not all antibodies that bind to conformationally intact capsids are neutralizing. Several assays for the determination of neutralizing antibodies have been developed, some of which could be applied to clinical trial monitoring (182). The in vitro HPV11 neutralization assay is very sensitive, but it requires infectious virus, and this is not available for all relevant HPV types (183). However, HPV 16 has recently been propagated in xenografted SCID mice and used successfully to detect HPV16-specific neutralizing antibodies $(184,185)$. The BPV1 pseudotype and the HPV33 pseudoinfection assays, which do not depend on infectious particles, may also prove applicable to the clinical setting (186, 187).

Evaluation of cellular immunity includes the measurement of HPV-specific CTLs. Most CTL assays depend on the restimulation of CD8 cells in vitro which are then tested for their ability to kill HPV-infected target cells. Such assays are labor-intensive, and may underestimate the true frequency of HPV-specific CTLs. Recently, different approaches to assessing CTLs in vitro have been developed. These include the measurement of circulating virus-specific T cells using the HLA tetramer assay, and the measurement of gamma-interferon release by ELISPOT $(188,189)$. These assays correlate well with conventional measurements of CTLs, and they have the advantage of being much more sensitive as well as requiring fewer in vitro restimulations.

\subsection{Cost, ease of implementation and stability.}

Vaccines destined for widespread prophylactic use would need to be produced in quantity in a form that is sufficiently stable for distribution, without the need for storage conditions that would be difficult to implement in the field. In addition, a regime involving a single immunization would be preferable to one requiring multiple injections. Cost is also a consideration, although the US $\$ 4.5$ billion a year spent on diagnosing borderline changes in the cervix alone puts the potential economic benefit of prophylactic vaccination into perspective.

Some therapeutic vaccination strategies require the vaccine to be tailored for individual patients (eg dendritic cell culture ex vivo for reinfusion, selection of peptides according to host HPV and HLA type); such treatments are likely to be more costly to implement than strategies where all eligible patients receive the same vaccine.

\subsection{Is there any reason why HPV vaccines won't work?}

Although many infectious agents against which vaccines have been developed successfully gain access to their hosts across mucosal surfaces, the majority then spread systemically, where they are exposed to systemic immunosurveillance. The HPV types under consideration for vaccine development are mainly sexually transmitted, and localize to anogenital sites. All current vaccine protocols are based on systemic immunization; whether such an approach will be successful in generating relevant mucosal immunity can only be answered by clinical trials. If successful, HPV vaccines would be the first examples of a vaccine against sexually transmitted disease.

All tumors are genetically unstable, and cervical tumor variants may arise which can escape even artificially induced cellular immunity. Importantly, HLA expression (a critical component of all cell mediated immune responses) is altered in cervical disease, with a high rate of HLA class I downregulation as well as up-regulation of HLA class II expression $(190,191)$. The former is a common feature of most tumor cells and is caused by many different mechanisms, but it is likely to compromise the efficacy of vaccines aimed at generating a CTL response (192). Loss of HLA expression on metastatic tumor cells is correlated with a significant decrease of tumor-infiltrating CD8+ T lymphocytes (193). Whilst altered HLA expression is more extensive in established tumors, the observation that HLA down-regulation occurs in progressing CIN lesions is important, as is the hormone-induced decrease in HLA class I expression seen in HPV-infected tumor cell lines (194, 195). The reason for upregulation of HLA class II expression on tumor cells is not clear, but it can be imagined that inappropriate HLA class II expression could result in anergy or indeed may reflect an inappropriate cytokine environment, perhaps favoring a type- 2 rather than a type 1 response.

\section{SUMMARY}

The development of simple effective prophylactic vaccines against HPV-16,- 18 and -6/11would have a considerable beneficial effect on the morbidity and mortality associated with HPV infection. The successful implementation of such vaccines would eventually preclude the necessity for therapeutic vaccines against these HPV types. It follows that with time, there would be no reason why eradication of commoner HPV types could not be achieved. Subsequent eradication of less common HPV types employing the same strategies should then be straightforward.

\section{ACKNOWLEDGEMENTS}

Margaret Duggan-Keen, Simon Stacey and Peter Stern are supported by the Cancer Research Campaign. Michael 
Brown is supported by the Christie Hospital NHS Trust Endowment Fund.

\section{REFERENCES}

1. Van Ranst, M, R. Tachezy \& R. D. Burk: Human Papillomaviruses: A Neverending Story? In: Papillomavirus Reviews: Current Research on Papillomaviruses. Eds: C. Lacey, Leeds University Press, Leeds, 1-19 (1996)

2. Derkay, C. S.: Task force on recurrent respiratory papillomas. Arch Otolaryngol Head Neck Surg 121, 1386-91 (1995)

3. IARC: The Human Papillomaviruses. In: Monographs on the evaluation of the carcinogenic risks to humans. Eds: IARC, Lyon, (1995)

4. Munoz, N.: Human papillomavirus and cervical cancer: epidemiological evidence. In: New Developments in Cervical Cancer Screening and Prevention. Eds: E. Franco and J. Monsonego, Blackwell Science, Oxford, 3-13 (1997)

5. Walboomers, J. M. M., M. V. Jacobs, J. W. van Oostveen, A. J. C. van den Brule, P. J. F. Snijders \& C. J. L. M. Meijer: Detection of human papillomavirus infections and possible clinical implications. In: Human Papillomavirus Infections in Dermatovenereology. Eds: G. Gross and G. von Krogh, CRC Press, London, Tokyo, New York, 341-64 (1997)

6. Pisani, P., D. M. Parkin \& J. Ferlay: Estimates of the worldwide mortality from eighteeen major cancers in 1985. Implications for prevention and projections of future burden. Int J Cancer 55, 891-903 (1995)

7. Van den Brule, A. J. C., J. M. M. Walboomers, M. Du Maine, P. Kenemans \& C. J. L. M. Meijer: Difference in prevalence of human papillomavirus genotypes in cytomorphologically normal cervical smears is associated with a history of cervical intra-epithelial neoplasia. Int J Cancer 48, 404-8 (1991)

8. De Roda Husman, A. M., J. M. M. Walboomers, C.J.L. M. Meijer, E. K. J. Risse, M. E. I. Schipper, T. M. Helmerhorst, O. P. Bleker, A. J. C. Van Den Brule \& P. J. F. Snijders: Analysis of cytomorphologically abnormal cervical scrapes for the presence of 27 mucosotropic human papillomavirus genotypes using polymerase chain reaction. Int J Cancer 56, 802-6 (1994) 9. Munoz, N. \& F. X. Bosch: Current views on the epidemiology of HPV and cervical cancer. In: Papillomavirus Reviews: Current Research on Papillomaviruses. Ed: C. Lacey, Leeds University Press, Leeds, 227-37 (1996)

10. Laara, E., N. E. Day \& M. Hakama: Trends in mortality from cervical cancer in the Nordic countries: association with organised screening programs. Lancet I, 1247-9 (1987)

11. Hakama, M. \& K. Luohivuori: A screening programme for cervical cancer that worked. Cancer Surv 7, 403-16 (1988)
12. MacGregor, J. E., S. M. Moss, D. M. Parkin \& N. E. Day: A case-control study of cervical cancer screening in North-East Scotland. B M J 290, 1543-6 (1985)

13. Sigurdsson, K.: Effect of organised screening on the risk of cervical cancer. Evaluation of screening activity in Iceland. Int J Cancer 54, 563-70 (1993)

14. Chow, L. T. \& T. R. Broker: Small DNA tumor viruses. In: Viral Pathogenesis. Eds: N. Nathanson, R. Ahmed, F. GonzalezScarano, D. E. Griffin, K. V. Holmes, F. A. Murphy and H. L. Robinson, Lippincott-Raven, Philadelphia, 267-301 (1997)

15. Roden, R. B., R. Kirnbauer, A. B. Jenson, D. R. Lowy \& J. T. Schiller: Interaction of papillomaviruses with the cell surface. J Virol 68, 7260-6 (1994)

16. Evander, M., I. H. Frazer, E. Payne, Y. M. Qi, K. Hengst $\&$ N. A. J. McMillan: Identification of the alpha (6) integrin as a candidate receptor for papillomaviruses. $J$ Virol 71, 2449-56 (1997)

17. Liu, J. S., S. R. Kuo, T. R. Broker \& L. T. Chow: The functions of human papillomavirus type $11 \mathrm{E} 1, \mathrm{E} 2$ and E2c proteins in cell-free DNA replication. J Biol Chem 270, 2728391 (1995)

18. Doorbar, J.: The E4 proteins and their role in the viral life cycle. In: Papillomavirus Reviews: Current Research on Papillomaviruses. Ed: C. Lacey, Leeds University Press., Leeds, 31-8 (1996)

19. Auvinen, E., K. Crusius, B. Steuer \& A. Alonso: Human papillomavirus type 16 E5 protein (review). Int J Oncol 11, 1297-304 (1997)

20. Crook, T. \& K. H. Vousden: HPV oncoprotein function. In: Papillomavrius Reviews: Current Research on Papillomaviruses. Ed: C. Lacey, Leeds University Press, Leeds, 55-60 (1996)

21. Cullen, A. P., R. Reid, M. Campion \& T. Lorincz: Analysis of the physical state of different human papillomavirus DNAs in intraepithelial neoplasia and invasive cervical carcinoma. $J$ Virol 65, 606-12 (1991)

22. Stoler, M. H., C. R. Rhodes, A. Whitbeck, S. M. Wolinsky, L. T. Chow \& T. R. Broker: Human papillomavirus type 16 and 18 gene expression in cervical neoplasias. Hum Pathol 23, 117 28 (1992)

23. Jeon, S. \& P. F. Lambert: Integration of human papillomavirus type 16 DNA into the human genome leads to increased stability of E6 and E7mRNAs: implications for cervical carcinogenesis. Proc Natl Acad Sci USA 92, 1654-8 (1995)

24. Atkin, N. B.: Cytogenetics of carcinoma of the cervix uteri: a review. Cancer Genet Cytogenet 95, 33-9 (1997)

25. Rader, J. S., T. Kamarasova, P. C. Huettner, L. Li, Y. Li \& D. S. Gerhard: Allelotyping of all chromosomal markers in invasive cervical cancer. Oncogene 13, 2737-41 (1996)

26. Mullokandov, M. R., N. G. Kholodilov, N. B. Atkin, R. D. Burk, A. B. Johnson \& H. P. Klinger: Genomic alterations in 
cervical carcinoma: losses of chromosome heterozygosity and human papilloma virus tumor status. Cancer Res 56, 197-205 (1996)

27. Zhou, J., X. Y. Sun, D. J. Stenzl \& I. H. Frazer: Expression of vaccinia recombinant HPV $16 \mathrm{~L} 1$ and L2 ORF proteins in epithelial cells is sufficient for assembly of HPV virion-like particles. Virology 185, 251-7 (1991)

28. Kirnbauer, R., F. Booy, N. Cheng, D. R. Lowy \& J. T. Schiller: Papillomavirus L1 major capsid protein self-assembles into virus-like particles that are highly immunogenic. Proc Natl Acad Sci USA 89, 12180-4 (1992)

29. Laga, M., J. P. Icenogle, R. Marsella, A. T. Manoka, N. Nzila, R. W. Ryder, S. H. Vermund, W. L. Heyward, A. Nelson \& W. C. Reeves: Genital papillomavirus infection and cervical dysplasia - opportunistic complications of HIV infection. Int. J. Cancer 48, 682-8 (1992)

30. Garzetti, G. G., A. Ciavattini, L. Buttini, A. Vecchi \& M. Montroni: Cervical dysplasia in HIV-seropositive women - role of human papillomavirus infection and immune status. Gynecol Obstet Invest 40, 52-6 (1994)

31. Petry, K. W., D. Scheffel, U. Bode, T. Gabrysiak, H. Kochel, E. Kupsch, M. Glaubitz, S. Niesert, H. Kuhnle \& I. Schedel: Cellular immunodeficiency enhances the progression of human papillomavirus-associated cervical lesions. Int J Cancer 57, 836-40 (1994)

32. Lutzner, M. A.: Papillomavirus lesions in immunodepression and immunosuppression. Clin Dermatol 3, 165-9 (1985)

33. Ho, G. Y., R. D. Buck, S. Klein, A. S. Kadish, C. J. Chang, P. Palan, J. Basu, R. Tachezy, R. Lewis \& S. Romney: Persistent genital human papillomavirus infection as a risk factor for persistent cervical dysplasia. J Natl Cancer Inst 87, 1365-71 (1995)

34. Remmink, A. J., J. M. M. Walboomers, T. M. Helmerhorst, F. J. Voorhorst, L. Rozendaal, E. J. K. Risse, C. J. L. M. Meijer \& P. Kenemans: The presence of persistent high-risk HPV genotypes in dysplastic cervical lesions is associated with progressive disease: natural history up to 36 months. Int. J. Cancer 61, 306-11 (1995)

35. Syrjanen, K. J.: Natural history of genital human hapillomavirus infections. In: Papillomavirus Reviews: Current Research on Papillomaviruses. Ed: C. Lacey, Leeds University Press, Leeds, 189-206 (1996)

36. Storey, A., M. Thomas, A. Kalita, C. Harwood, D. Gardiol, F. Mantovani, J. Breuer, I. M. Leigh, G. Matlashewski \& L. Banks: Role of a p53 polymorphism in the development of human papillomavirus-associated cancer. Nature 235, 229-34 (1998)

37. Matzinger, P.: Tolerance,danger, and the extended family. Annu Rev Immunol 12, 991-1045 (1994)
38. Mosman, T. R. \& S. Sad: The expanding universe of T-cell subsets: Th1, Th2 and more. Immunol Today 17, 138-46 (1996) 39. Kelso, A.: Th1 and Th2 subsets: paradigms lost? Immunol Today 16, 374-9 (1995)

40. Allen, J. E. \& R. M. Maizels: Th1-Th2: reliable paradigm or dangerous dogma? Immunol Today 18, 387-92 (1997)

41. Ridge, J. P., F. Di Rosa \& P. Matzinger: A conditioned dendritic cell can be a temporal bridge between a CD4+ T-helper and a T-killer cell. Nature 393, 474-8 (1998)

42. Bennett, S. R. M., F. R. Carbone, F. Karamalis, R. A. Flavell, J. F. A. P. Miller \& W. R. Heath: Help for cytotoxic Tcell responses is mediated by CD40 signalling. Nature 393, 47880 (1998)

43. Schoenberger, S. P., R. E. M. Toes, E. I. H. Van der Voort, R. Offringa \& C. J. M. Melief: T cell help for cytotoxic T lymphocytes is mediated by CD40-CD40L interactions. Nature 393, 480-3 (1998)

44. White, H. D., K. M. Crassi, A. L. Givan, S. J.E., J. L. Gonzalez, V. A. Memoli, W. R. Green \& C. R. Wira: CD3(+)CD8(+)CTL activity within the human female reproductive tract - influence of stage of the menstrual cycle and menopause. J Immunol 158, 3017-27 (1997)

45. Coleman, N., H. D. L. Birley, A. M. Renton, N. F. Hanna, B. K. Ryait, M. Byrne, D. Taylor Robinson \& M. A. Stanley: Immunological events in regressing genital warts. Am J Clin Pathol 102, 768-74 (1994)

46. Arany, I. \& S. K. Tyring: Status of local cellular immunity in interferon-responsive and -nonresponsive human papillomavirus-associated lesions. Sex Transm Dis 23, 475-80 (1996)

47. Hong, K., C. E. Greer, N. Ketter, G. VanNest \& X. Paliard: Isolation and characterisation of human papillomavirus type 6specific T cells infiltrating genital warts. J Virol 71, 6427-32 (1997)

48. Tay, S. K., D. Jenkins, P. Maddox, M. Campion \& A. Singer: Subpopulations of Langerhans' cells in cervical neoplasia. Br. J. Obstet. Gynaecol. 94, 10-5 (1987)

49. Viac, J., R. I. Guerin, Y. Chardonnet \& A. Bremond: Langerhans cells and epithelial modifications in cervical intraepithelial neoplasia: correlation with human papillomavirus infections. Immunobiol 180, 328-38 (1990)

50. Morelli, A. E., C. Sananes, G. Di Paola, A. Paredes \& L. Fainboim: Relationship between types of human papillomavirus and Langerhans cells in cervical condyloma and intraepithelial neoplasia. Am J Clin Pathol 99, 200-6 (1992)

51. Lehtinen, M., I. Rantala, A. Tiovonen, H. Luoto, R. Aine, K. Lauslahti, A. Ylaoutinen, U. Romppanen \& J. Paavonen: Depletion of Langerhans cells in cervical HPV infection is associated with replication of the virus. APIMS 101, 833-7 (1993) 
52. Bal, V., A. McIndoe, G. Denton, D. Hudson, G. Lombardi \& J. Lamb: Antigen presentation by keratinocytes induces tolerance in human T cells. Eur J Immunol 20, 1893-7 (1990) 53. Goodman, R. E., F. Nestle, Y. M. Naidu, J. M. Green, C. B. Thompson, B. J. Nickloff \& L. A. Turka: Keratinocytederived $\mathrm{T}$ cell costimulation induces preferential production of IL-2 and IL-4 but not IFN gamma. J Immunol 152, 5189-98 (1994)54. Ghosh, A. K. \& M. Moore: Tumour-infiltrating lymphocytes in cervical carcinoma. Eur J Cancer 28A, 1910-6 (1992)

55. Hilders, C. G. J. M., J. G. A. Houbiers, H. H. V. Claasen, R. W. Veldhuizen \& F. G.J.: Association between HLAexpression and infiltration of immune cells in cervical carcinoma. Lab Invest 69, 651-9 (1993)

56. Hilders, C. G. J. M., L. Ras, J. D. H. Van Eendenburg, Y. Nooyen \& G. J. Fleuren: Isolation and characterizaton of tumour-infiltrating lymphocytes from cervical carcinoma. Int $J$ Cancer 57, 805-13 (1994)

57. Evans, E.-M., S. Man, A. S. Evans \& L. K. Borysiewicz: Infiltration of cervical cancer tissue with human papillomavirusspecific cytotoxic T lymphocytes. Cancer Res 57, 2943-50 (1997)

58. Shepherd, P. S., A. J. Rowe, J. C. Cridland, T. Coletart, P. Wilson \& J. C. Luxton: Proliferative T-cell responses to human papillomavirus type $-16 \mathrm{~L} 1$ peptides in patients with cervical dysplasia. J Gen Virol 77, 593-602 (1996)

59. DeGruijl, T. D., H. J. Bontkes, J. M. M. Walboomers, P. Coursaget, M. J. Stukart, C. Dupuy, E. Kueter, R. H. M. Verheijen, T. J. M. Helmerhorst, R. H. M. Verheijen, T. J. M. Helmerhorst, M. F. Duggan-Keen, F. R. A. Stevens, P. A. Dyer, P. L. Stern, C. J. L. M. Meijer \& R. J. Scheper: Differential Th and $\mathrm{IgG}$ responses to HPV-16 L1 containing virus-like particles in relation to cervical intraepithelial neoplasia and HLA genotype. $J$ Gen Virol in press

60. Luxton, J. C., A. J. Rowe, J. C. Cridland, T. Coletart, P. Wilson \& S. P.S.: Proliferative T-cell responses to the human papillomavrius type-16 E7 protein in women with cervical dysplasia and cervical carcinoma and in healthy individuals. $J$ Gen Virol 77, 1585-93 (1996)

61. Kirnbauer, R., N. L. Hubbert, C. M. Wheeler, T. M. Becker, D. R. Lowy \& J. T. Schiller: A virus-like particle enzyme-linked-immunosorbent -assay detects serum antibodies in a majority of women infected with human papillomavirus type-16. J Natl Cancer Inst 86, 494-9 (1994)

62. Nonnenmacher, B., N. L. Hubbert, R. Kirnbauer, K. V. Shah, N. Munoz, F. X. Bosch, S. Desanjose, R. Viscidi, D. R. Lowy \& J. T. Schiller: Serologic response to human papillomavirus type-16 (HPV-16) virus-like particles in HPV-16 DNA-positive invasive cervical-cancer and cervical intraepithelial neoplasia grade III patients and controls from Colombia and Spain. J Infect Dis 172, 19-24 (1995)

63. Dillner, J., I. Kallings, C. Brihmer, P. Sikstrom, P. Koskela, M. Lehtinen, J. T. Schiller, M. Sapp \& P. A. Mardh: Seropositivities to human papillomavirus type 16 , type 18 , or type 33 capsids and to Chlamydia trachomatis are markers of sexual behaviour. J Infect Dis 173, 1394-8 (1996)

64. Carter, J. J., L. A. Koutsky, G. C. Wipf, N. D. Christensen, S. K. Lee, J. Kuypers, N. Kiviat \& D. A. Galloway: The natural history of human papillomavirus type-16 capsid antibodies among a cohort of university women. J Infect Dis 174, 927-36 (1996)

65. Lehtinen, M., J. Dillner, P. Knekt, T. Luostarinen, A. Aromaa, R. Kirnbauer, P. Koskela, J. Paavonen, R. Peto, J. T. Schiller \& M. Hakama: Serologically diagnosed infection with human papillomavirus type 16 and risk for subsequent development of cervical carcinoma: nested case control study. B $M J 312$, 537-9 (1996)

66. Wideroff, L., M. H. Schiffman, B. Nonnenmacher, N. Hubbert, R. Kirnbauer, C. E. Greer, D. Lowy, A. T. Lorincz, M. M. Manos, A. G. Glass \& D. R. Scott: Evaluation of seroreactivity to human papillomavirus type 16 virus-like particles in an incident case-control study of cervical neoplasia. J Infect Dis 172, 1425-30 (1995)

67. Wikstrom, A., G. J. J. Vandoornum, W. G. V. Quint, J. T. Schiller \& J. Dillner: Identification of human papillomavirus seroconversions. J Gen Virol 76, 529-39 (1995)

68. De Gruijl, T. D., H. J. Bontkes, M. J. Stukart, J. M. M. Walboomers, J. T. Schiller, B. S. Groot, M. R. Chaboud, A. J. Remmink, R. H. M. Verheijen, T. J. M. Helmerhorst, C. J. L. M. Meijer \& R. J. Scheper: Immunoglobulin G responses against human papillomavirus type 16 virus-like particles in a prospective nonintervention cohort study of women with cervical intraepithelial neoplasia. J Natl Cancer Inst 89, 630-8 (1997)

69. Wang, Z. H., B. G. Hansson, O. Forslund, L. Dillner, M. Sapp, J. T. Schiller, B. Bjerre \& J. Dillner: Cervical-mucus antibodies against human papillomavirus type 16, type 18, and type 33 capsids in relation to presence of viral DNA. J Clin Microbiol 34, 3056-62 (1996)

70. Leiserowitz, G. S., K. S. Hall, C. A. Foster, M. E. Hitchcock, N. D. Christensen, K. Heim \& L. H. Smith: Detection of serologic neutralizing antibodies against HPV-11 in patients with condyloma acuminata and cervical dysplasia using an in vitro assay. Gynecol Oncol 66, 295-9 (1997)

71. Altmann, A., I. Jochmus-Kudielka, R. Frank, H. Gausepohl, U. Moebius, L. Gissman \& S. C. Meuer: Definition of immunogenic determinants of the human papillomavirus type 16 nucleoprotein E7. Eur J Cancer 28, 326-33 (1992)

72. De Gruijl, T. D., H. J. Bontkes, M. J. Stukart, J. M. M. Walboomers, A. J. Remmink, R. H. M. Verheijen, T. J. M. 
Helmerhorst, C. J. L. M. Meijer \& R. J. Scheper: T cell proliferative responses against human papillomavirus type16 E7 oncoprotein are most prominent in cervical intraepithelial neoplasia patients with a persistent viral infection. J Gen Virol 77, 2183-91 (1996)

73. DeGruijl, T. D., H. J. Bontkes, J. M. M. Walboomers, M. J. Stukart, F. S. Doekhie, A. J. Remmink, T. J. M. Helmerhorst, R. H. M. Verheijen, M. F. Duggan-Keen, P. L. Stern, C. J. L. M. Meijer \& R. J. Scheper: Differential T helper cell responses to human papillomavirus type $16 \mathrm{E} 7$ related to viral clearance or persistence in patients with cervical neoplasia: A longitudinal study. Cancer Res 58, 1700-6 (1998)

74. Kadish, A. A., S. L. Romney, R. Ledwidge, R. Tindle, G. J. P. Fernando, S. Y. Zee, M. A. Vanranst \& R. D. Burk: Cellmediated immune-responses to E7 peptides of human papillomavirus (HPV) type-16 are dependent on the HPV type infecting the cervix whereas serological reactivity is not typespecific. J Gen Virol 75, 2277-84 (1994)

75. Kadish, A. S., G. Y. F. Ho, R. D. Burk, Y. X. Wang, S. L. Romney, R. Ledwidge \& R. H. Angeletti: Lymphoproliferative responses to human papillomavirus (HPV) type 16 proteins E6 and E7: outcome of HPV infection and associated neoplasia. $J$ Natl Cancer Inst 89, 1285-93 (1997)

76. Luxton, J. C., R. C. Rose, T. Coletart, P. Wilson \& P. S. Shepherd: Serological and T-helper cell responses to human papillomavirus type $16 \mathrm{~L} 1$ in women with cervical dysplasia or cervical carcinoma and in healthy controls. J Gen Virol 78, 91723 (1997)

77. Nakagawa, M., D. P. Stites, S. Farhat, A. Judd, A. B. Moscicki, A. J. Canchola, J. F. Hilton \& J. M. Palefsky: T-cell proliferative response to human papillomavirus type-16 peptides - relationship to cervical intraepithelial neoplasia. Clin Diag Lab Immunol 3, 205-10 (1996)

78. Tsukui, T., A. Hildesheim, M. Schiffman, J. Lucci, D. Contois, P. Lawler, B. B. Rush, A. T. Lorncz, A. Corrigan, R. D. Burk, W. Qu, M. A. Marshall, D. Mann, M. Carrington, M. Clerici, G. M. Shearer, D. P. Carbone, D. R. Scott, R. A. Houghton \& J. A. Berzofsky: Interleukin 2 production in vitro by peripheral lymhocytes in response to human papillomavirusderived peptides: correlation with cervical pathology. Cancer Res 56, 3967-74 (1996)

79. Muller, M., R. P. Viscidi, V. Ulken, J. N. B. Bavinck, P. M. Hill, S. G. Fisher, R. Reid, N. Munoz, A. Schnieder, K. V. Shah \& L. Gissman: Antibodies to the E4, E6 and E7 proteins of human papillomavirus (HPV) type-16 in patients with HPVassociated diseases and in the normal populations. $J$ Invest Dermatol 104, 138-41 (1995)

80. Kirchnak, V., J. Vagner, A. Suchankova, M. Krcmar, L. Ritterova \& V. Vonka: Synthetic peptides derived from E7 region of human papillomavirus type 16 used as antigens in ELISA. J Gen Virol 71, 2719-24 (1990)

81. De Gruijl, T. D., H. J. Bontkes, J. M. M. Walboomers, M. J. Stukart,B.M.E. von Blomberg-vanderFlier, P. Herbrink, A. J. Remmink, R. H. M. Verheijen, T. J. M. Helmerhorst, C. J. L. M. Meijer \& R. J. Scheper: Analysis of IgG reactivity against human papillomavirus type-16 E7 in patients with cervical intraepithelial neoplasia indicates an association with clearance of viral infection: a prospective study. Int J Cancer $68,731-8$ (1996)

82. Galloway, D. A.: HPV Serology: Another Update. In: Papillomavirus Reviews: Current Research on Papillomaviruses. Ed: C. Lacey , Leeds University Press., Leeds, 113-9 (1996)

83. Kast, W. M., M. P. Remco, J. W. Drijfhout \& C. J. M. Melief: HLA-A2.1 restricted candidate CTL epitopes of human papillomavirus type 16 E6 and E7 proteins identified by using the processing defective human cell line T2. J Immunother 14, 115-20 (1993)

84. Kast, W. M., R. M. Brandt, J. Sidney, J. W. Drijhout, R. T. Kubo, H. M. Grey, C. J. Melief \& A. Sette: Role of HLA-A motifs in identification of potential CTL epitopes in human papillomavrius type E6 and E7 proteins. J Immunol 152, 390412 (1994)

85. Ressing, M. E., A. Sette, R. M. P. Brandt, J. Ruppert, P. A. Wentworth, M. Hartman, C. Oseroff, H. M. Grey, C. J. M. Melief \& W. M. Kast: Human CTL epitopes encoded by human papillomavirus type $16 \mathrm{E} 6$ and E7 identified through in vivo and in vitro immunogenicity studies of HLA-A*0201-binding peptides. J Immunol 154, 5934-43 (1995)

86. Ressing, M. E., W. J. Van Driel, E. Celis, A. Sette, R. M. P. Brandt, M. Hartman, J. D. H. Anholts, G. M. T. Schreuder, W. B. Ter Harmsel \& G. R. Fleuren: Occasional memory cytotoxic T-cell responses of patients with human papillomavirus type 16positive cervical lesions against a human leukocyte antigenA*0201 restricted E7-encoded epitope. Cancer Res 56, 582-8 (1996)

87. Alexander, M., M. L. Salgaller, E. Celis, A. Sette, W. A. Barnes, S. A. Rosenberg \& M. A. Steller: Generation of tumourspecific cytolytic $\mathrm{T}$ lymphocytes from peripheral blood of cervical cancer patients by in vitro stimulation with a synthetic human papillomavirus type 16 E7 epitope. Am J Obstet Gynecol 175, 1586-93 (1996)

88. Nimako, M., A. N. Fiander, G. W. G. Wilkinson, L. K. Borysiewicz \& S. Man: Human papillomavirus-specific cytotoxic $\mathrm{T}$ lymphocytes in patients with cervical intraepithelial neoplasia grade III. Cancer Res 57, 4855-61 (1997)

89. Nakagawa, M., D. P. Stites, S. Farhat, J. R. Sisler, M. B., F. Kong, A.-B. Moscicki \& J. M. Palefsky: Cytotoxic T lymphocyte responses to E6 and E7 proteins of human 
papillomavirus type 16: Relationship to cervical intraepithelial neoplasia. J Infect Dis 175, 927-31 (1997)

90. Chen, L. P., E. K. Thomas, S.-L. Hu, I. Hellstrom \& K. E. Hellstrom: Human papillomavirus type 16 nucleoprotein E7 is a tumor rejection antigen. Proc. Natl. Acad. Sci. USA 88, 110-4 (1991)

91. Chen, L., M. T. Mizuno, M. C. Singhal, S.-L. Hu, D. A. Galloway, I. Hellstrom \& K. E. Hellstrom: Induction of cytotoxic $\mathrm{T}$ lymphocytes specific for a syngeneic tumor expressing the E6 oncoprotein of human papillomavirus type 16. J. Immunol. 148, 2617-21 (1992)

92. McLean, C. S., J. S. Sterling, J. Mowat, A. A. Nash \& M. A. Stanley: Delayed-type hypersensitivity response to the human papillomavirus type 16 in a mouse model. J Gen Virol 74, 239-45 (1993)

93. Chambers, M. A., Z. Wei, N. Coleman, A. A. Nash \& M. A. Stanley: Natural presentation of human papillomavirus type$16 \mathrm{E} 7$ protein to immunocompetent mice results in antigenspecific sensitisation or sustained unresponsiveness. Eur $J$ Immunol 24, 738-45 (1994)

94. Chambers, M. A., S. N. Stacey, J. R. Arrand \& M. A. Stanley: Delayed-type hypersensitivity responses to human papillomavirus type-16 E6 protein in a mouse model. J Gen Virol 75, 165-9 (1994)

95. Herd, K., G. J. P. Fernando, L. A. Dunn, I. H. Frazer, P. Lambert \& R. W. Tindle: E7 oncoprotein of human papillomavirus type 16 expressed constitutively in the epidermis has no effect on E7-specific B- or Th-repertoires or on the immune response induced or sustained after immunization with E7 peptide. Virology 231, 155-65 (1997)

96. Doan, T., M. Chambers, M. Street, G. J. P. Fernando, K. Herd, P. Lambert \& R. Tindle: Mice expressing the E7 oncogene of HPV16 in epithelium show central tolerance, and evidence of peripheral anergising tolerance to E7-encoded cytotoxic T lymphocyte epitopes. Virology 244, 352-64 (1998) 97. Melero, I., M. C. Singhal, P. McGown, H. S. Haugen, J. Blake, K. E. Hellstrom, G. Yang, C. H. Clegg \& L. Chen: Immunological ignorance of an E7-encoded cytolytic Tlymphocyte epitope in transgenic mice expressing the E7 and E6 oncogenes of human papillomavirus type 16. J Virol 71, 39984004 (1997)

98. Gaukroger, J. M., A. Bradley, L. Chandrachud, W. F. H. Jarrett \& M. S. Campo: Interaction between bovine papillomavirus type 4 and cocarcinogens in the production of malignant tumors . J Gen Virol 74, 2275-80 (1993)

99. Sasagawa, T., P. Pushko, G. Steers, S. E. Gschmeissner, M. A. Hajibagheri, J. Finch, L. Crawford \& M. Tomassino: Synthesis and assembly of virus-like particles of human papillomaviruses type 6 and type 16 in fission yeast Schizosaccharomyces pombe. Virology 206, 126-35 (1995)
100. Hofmann, K., J. Cook, J. Joyce, D. R. Brown, L. D. Schulz, H. A. George, M. Rosolowsky, K. H. Fife \& K. U. Jansen: Sequence determination of human papillomavirus $6 \mathrm{a}$ and assembly of virus-like particles in saccharomyces cerevisiae. Virology 209, 506-18 (1995)

101. Rose, R. C., W. Bonnez, R. C. Reichman \& R. L. Garcea: Expression of human papillomavirus type $11 \mathrm{~L} 1$ protein in insect cells: in vivo and in vitro assembly of virus-like particles. $J$ Virol 67, 1936-44 (1993)

102. Li, M. L., T. P. Cripe, P. A. Estes, M. K. Lyon, R. C. Rose \& R. L. Garcea: Expression of the human papillomavrius type $11 \mathrm{~L} 1$ capsid protein in Escherichia coli: characterisation of protein domains involved in DNA binding and capsid assembly. J Virol 71, 2988-95 (1997)

103. Breitburd, F., R. Kirnbauer, N. L. Hubbert, B. Nonnenmacher, C. Trindinh-Desmarquet, G. Orth, J. T. Schiller \& D. R. Lowy: Immunization with virus-like particles from cottontail rabbit papillomavirus (CRPV) can protect against experimental CRPV infection. J Virol 69, 3959-63 (1995)

104. Jansen, K. U., M. Rosolowsky, L. D. Schultz, H. Z. Markus, J. C. Cook, J. J. Donnelly, D. Martinez, R. W. Ellis \& A. R. Shaw: Vaccination with yeast-expressed cottontail rabbit papillomavirus (CRPV) virus-like particles protects rabbits from CRPV-induced papilloma formation. Vaccine 13, 1509-14 (1995)

105. Christensen, N. D., C. A. Reed, N. M. Cladel, R. Han \& J. W. Kreider: Immunization with virus like particles induces long-term protection of rabbits against challenge with cottontail rabbit papillomavirus. $J$ Virol 70, 960-5 (1996)

106. Suzich, J. A., S. Ghim, F. J. Palmer-Hill, W. J. White, J. K. Tamura, J. A. Bell, J. A. Newsome, A. B. Jenson \& R. Schlegel: Systemic immunization with papillomavirus L1 protein completely prevents the development of viral mucosal papillomas. Proc. Natl. Acad. Sci. USA 92, 11553-7 (1995)

107. Kirnbauer, R., L. M. Chandrachaud, B. W. O'Neill, G. J. Grindlay, A. Armstrong, G. M. McGarvie, J. T. Schiller, D. R. Lowy \& M. S. Campo: Virus-like particles of bovine papillomavirus type 4 in prophylactic and therapeutic immunization . Virology 219, 37-44 (1996)

108. Lowe, R. S., D. R. Brown, J. T. Bryan, J. C. Cook, H. A. George \& K. J. Hofmann: Human papillomavirus type 11 neutralizing antibodies in the serum and genital mucosal secretions of African green monkeys immunized with HPV-11 virus-like particles expressed in yeast. J Infect Dis 176, 1141-5 (1997)

109. Dupuy, C., D. Buzoni Gatel, A. Touze, P. LeCann, D. Bout \& P. Coursaget: Cell mediated immunity induced in mice by HPV 16 L1 virus-like particles. 22, 219-25 (1997)

110. Muller, M., J. A. Zhou, T. D. Reed, C. Rittmuller, A. Burger, J. Gabelsberger, J. Braspenning \& L. Gissmann: 
Chimeric papillomavirus-like particles. Virology 234, 93-111 (1997)

111. Greenstone, H. L., J. D. Nieland, K. E. deVisser, M. L. H. DeBruijn, R. Kirnbauer, R. B. S. Roden, D. R. Lowy, W. M. Kast \& J. R. Schiller: Chimeric papillomavirus virus-like particles elicit anti-tumor immunity against the E7 oncoprotein in an HPV16 tumor model. Proc Natl Acad Sci USA 95, 1800-5 (1998)

112. Peng, S., I. H. Frazer, G. J. Fernando \& J. Zhou: Papillomavirus like particles can deliver defined CTL epitopes to the MHC class I pathway. Virology 240, 147-57 (1998)

113. Lin, Y.-L., R. Borenstein, R. Selvakumar, R. Ahmed \& F. O. Wettstein: Effective vaccination against papilloma development by immunization with L1 or L2 structural protein of cottontail rabbit papillomavirus. Virology 187, 612-9 (1992) 114. Lin, Y. L., L. A. Boreinstein, R. Ahmed \& F. O. Wettstein: Cottontail rabbit papillomavirus-L1 protein-based vaccines protection is achieved only with a full length, nondenatured product. J Virol 67, 4154-62 (1993)

115. Jarrett, W. F. H., K. T. Smith, B. W. O'Neil, J. M. Gaukroger, L. M. Chandrachaud, G. J. Grindlay, G. M. McGarvie \& M. S. Campo: Studies on vaccination against papillomaviruses - prophylactic and therapeutic vaccination with recombinant structural proteins. Virology 184, 33-42 (1991)

116. Chandrachud, M., G. J. Grindlay, G. M. McGarvie, B. W. ONeil, E. R. Wagner, W. F. H. Jarrett \& M. S. Campo: Vaccination of cattle with the N-terminus of L2 is necessary and sufficient for preventing infection by bovine papillomavirus-4. Virology 211, 204-8 (1995)

117. Gaukroger, J. M., L. M. Chandrachud, B. W. O'Neil, G. J. Grindlay, G. Knowles \& M. S. Campo: Vaccination of cattle with bovine papillomavirus type-4 L2 elicits the production of virus-neutralizing antibodies. J Gen Virol 77, 1577-83 (1996)

118. Selvakumar, R., L. A. Borenstein, Y. L. Lin, R. Ahmed \& F. O. Wettstein: Immunization with nonstructural proteins E1 and E2 of cottontail rabbit papillomavirus stimulates regression of virus-induced papillomas. J Virol 69, 602-5 (1995)

119. Selvakumar, R., R. Ahmed \& F. O. Wettsten: Tumor regression is associated with a specific immune response to the E2 protein of cottontail rabbit papillomavirus. Virology 208, 298-302 (1995)

120. Zhu, X., M. Tommasino, K. Vousden, E. Sadovnikava, R. Rappuoli, L. Crawford, M. Kast, C. J. M. Melief, P. C. L. Beverley \& H. J. Stauss: Both immunization with protein and recombinant vaccinia virus can stimulate CTL specific for the E7 protein of human papillomavirus 16 in H-2(D) mice. Scand $J$ Immunol 42, 557-63 (1995)

121. Speidel, K., W. Osen, S. Faath, I. Hilgert, R. Obst, J. Braspenning, F. Momburg, G. J. Hammerling \& H. G. Rammensee: Priming of cytotoxic T lymphocytes by five heat- aggregated antigens in vivo: conditions, efficiency, and relation to antibody responses. Eur J Immunol 27, 2391-9 (1997)

122. Tarpey, I., S. Stacey, J. Hickling, H. D. L. Birley, A. Renton, A. McIndoe \& D. H. Davies: Human cytotoxic T lymphocytes stimulated by endogenously processed human papillomavirus type $11 \mathrm{E} 7$ recognize a peptide containing a HLA-A2 (A0201) motif. Immunol 81, $222-7$ (1994)

123. Lacey, C. J. N., H. S. G. Thompson, E. F. Monteiro, M. L. Davies, T. O'Neill, F. P. Holding, R. E. Fallon \& J. S. Roberts: Phase IIa safety, immunogenicity and clinical responses induced by TA-GW, a therapeutic vaccine for clinical warts. (submitted)

124. Tindle, R. W.: Human papillomavirus vaccines for cervical cancer. Curr Opin Immunol 8, 643-50 (1996)

125. D'Amaro, F., J. G. A. Houbiers, J. W. Drijfhout, R. M. P. Brandt, R. Schipper, J. N. B. Bavinck, C. J. M. Melief \& W. M. Kast: A computer-program for predicting possible cytotoxic Tlymphocyte epitopes based on HLA class 1 peptide-binding motifs. Hum Immunol 43, 13-8 (1995)

126. Drijfhout, J. W., R. M. P. Brandt, J. D'Amaro, W. M. Kast \& C. J. M. Melief: Detailed motifs for peptide binding to HLA-A-*0201 derived from large random sets of peptides using a cellular binding assay. Hum Immunol 43, 1-12 (1995)

127. Stauss, H. J., H. Davies, E. Sadovnikova, B. Chain, M. Horowitz \& C. Sinclair: Induction of cytotoxic T lymphocytes with peptides in vitro: Identification of candidate T-cell epitopes in human papillomavirus. Proc Natl Acad Sci 89, 7871-5 (1992) 128. Sadovnikova, E., X. J. Zhu, S. M. Collins, J. Zhou, K. Vousden, L. Crawford, P. Beverley \& H. J. Stauss: Limitations of predictive motifs revealed by cytotoxic T-lymphocyte epitope mapping of the human papillomavirus E7 protein. Int Immunol 6, 289-96 (1994)

129. Feltkamp, M. C. W., H. L. Smits, M. P. M. Vierboom, R. P. Minnaar, B. M. de Jongh, J. W. Drijfhout, J. ter Schegget, C. J. M. Melief \& W. M. Kast: Vaccination with cytotoxic T lymphocyte epitope-containing peptide protects against a tumor induced by human papillomavirus type 16-transformed cells. Eur J Immunol 23, 2242-9 (1993)

130. Feltkamp, M. C. W., G. R. Vreugdenhil, M. P. M. Vierboom, E. Ras, S. H. van der Burg, J. ter Schegget, C. J. M. Melief \& W. M. Kast: Cytotoxic T lymphocytes raised against a subdominant epitope offered as a synthetic peptide eradicate human papillomavirus type 16-induced tumors . Eur J Immunol 25, 2638-42 (1995)

131. Lipford, G. B., S. Bauer, H. Wagner \& K. Heeg: Peptide engineering allows cytotoxic T-cell vaccination against human papilloma-virus tumour-antigen E6. Immunol 84, 298-303 (1995)

132. Fernando, G. J. P., D. J. Stenzel, R. W. Tindle, M. S. Merza, B. Morein \& I. H. Frazer: Peptide polymerization 
facilitates incorporation into ISCOMS and increases antigenspecific IgG2a production. Vaccine 13, 1460-7 (1995)

133. Tindle, R. W., S. Croft, K. Herd, K. Malcolm, A. F. Geczy, T. Stewart \& G. J. P. Fernando: A vaccine conjugate of iscar immunocarrier and peptide epitopes of the E7 cervical cancer-associated protein of human papillomavirus type-16 elicits specific TH1-type and TH2-type responses in immunized mice in the absence of oil-based adjuvants. Clin Exp Immunol 101, 265-71 (1995)

134. Jager, E., M. Ringhoffer, H. P. Dienes, M. Arand, J. Karbach, D. Jager, C. Ilsemann, M. Hagedorn, F. Oesch \& A. Knuth: Granulocyte-macrophage colony stimulating factor enhances immune responses to melanoma-associated peptides in vivo. Int J Cancer 67, 54-62 (1996)

135. Toes, R. E. M., R. Offringa, R. J. J. Blom, C. J. M. Melief \& W. M. Kast: Peptide vaccination can lead to enhanced tumor growth through specific T cell tolerance induction. Proc Natl Acad Sci USA 93, 7855-60 (1996)

136. Toes, R. E. M., E. I. H. van der Voort, S. P. Schoenberger, J. W. Drijfhout, L. van Bloois, G. Storm, W. M. Kast, R. Offringa \& C. J. M. Melief: Enhancement of tumor outgrowth through CTL tolerization after peptide vaccination is avoided by peptide presentation on dendritic cells. J Immunol 160, 4449-56 (1998)

137. Ellis, J. R. M., P. J. Keating, J. Baird, E. F. Hounsell, D. V. Renouf, M. Rowe, D. Hopkins, M. F. Duggan-Keen, J. Bartholomew, L. S. Young \& P. L. Stern: The association of an HPV-16 oncogene variant with HLA-B7 has implications for vaccine design in cervical cancer. Nat Med 1, 464-70 (1995) 138. Yamada, T., M. M. Manos, J. Peto, C. E. Greer, N. Munoz, F. X. Bosch \& C. M. Wheeler: Human papillomavirus type 16 sequence variation in cervical cancers: a worldwide perspective. J. Virol. 71, 2463-72 (1997)

139. Zehbe, I., E. Wilander, H. Delius \& M. Tomassino: Human papillomavirus 16 E6 variants are more prevalent in invasive cervical carcinoma than the prototype. Cancer Res 58, 829-33 (1998)

140. McNeil, C.: HPV Vaccine Treatment Trials Proliferate, Diversify. J Natl Cancer Inst 89, 280-1 (1997)

141. Behebani, A. M.: The smallpox story: life and death of an old disease. Microbiol Rev 47, 455-509 (1983)

142. Aurelian, L., C. C. Smith, M. Wachsman \& E. Paoletti: Immune responses to herpes simplex virus in guinea pigs (footpad model) and mice immunized with vaccinia virus recombinants containing herpes simplex glycoprotein D. Rev Inf Dis 13, S924-34 (1991)

143. Cooney, E. L., A. C. Collier, P. D. Greenberg, R. W. Coombs, J. Zarling, D. E. Arditti, M. C. Hoffman, S. Hu \& L. Corey: Safety of and immunological response to a recombinant vaccinia virus vaccine expressing HIV envelope glycoprotein. Lancet 337, 567-72 (1991)

144. Tsang, K. Y., S. Zaremba, C. A. Nieroda, M. Z. Zhu, M. Hamilton \& J. Schlom: Generation of human cytotoxic T cells for human carcinoembryonic antigen epitopes from patients immunized with recombinant vaccinia-CEA vaccines. $J$ Natl Cancer Inst 87, 982-90 (1995)

145. Zhou, J., A. McIndoe, H. Davies, X.-Y. Sun \& L. Crawford: The induction of cytotoxic T-lymphocyte precursor cells by recombinant vaccinia virus expressing human papillomavirus type 16 L1. Virology 181, 203-10 (1991)

146. Gao, L., B. Chain, C. Sinclair, L. Crawford, J. Zhou, J. Morris, X. Zhu \& H. Stauss: Immune response to human papillomavirus type-16 E6 gene in a live vaccina vector. J Gen Virol 75, 157-64 (1994)

147. Lin, K. Y., F. G. Guarnieri, K. F. Staveley-O=Carroll, H. I. Livitsky, J. T. August, D. M. Pardoll \& T. C. Wu: Treatment of established tumors with a novel vaccine that enhances major histocompatibility class II presentation of tumor antigen. Cancer Res 56, 21-6 (1996)

148. Borysiewicz, L. K., A. Fiander, M. Nimako, S. Man, G. W. G. Wilkinson, D. Westmorland, A. S. Evans, M. Adams, S. N. Stacey, M. E. G. Boursall, E. Rutherford, J. K. Hickling \& S. C. Inglis: A recombinant vaccinia virus encoding human papillomavirus types 16 and 18, E6 and E7 proteins as immunotherapy for cervical cancer. Lancet 347, 1523-7 (1996) 149. Carroll, M. W., W. W. Overwijk, R. S. Chamberlain, S. A. Rosenberg, B. Moss \& N. P. Restifo: Highly attenuated modified vaccinia virus Ankara (MVA) as an effective recombinant vector: A murine tumor model. Vaccine 15, 388-94 (1997)

150. Wang, M., V. Bronte, P. W. Chen, L. Gritz, D. Panicali, S. A. Rosenberg \& N. P. Restifo: Active immunotherapy of cancer with a nonreplicating recombinant fowlpox virus encoding a model tumour-associated antigen. J Immunol 154, 4685-92 (1995)

151. Freis, L. F., J, J. Taylor, E. K. Kauffman, B. Meignier, E. Paoletti \& S. Plotkin: Human safety and immunogenicity of a canarypox-rabies glycoprotein recombinant vaccine: an alternative poxvirus vector system. Vaccine 14, 428-34 (1996) 152. Pialoux, G., J. Excler, Y. Riviere, G. Gonzalezcnali, V. Feuillie, P. Coulad, J. C. Gluckman, T. J. Matthews, B. Meignier, M. P. Kieny, P. Gonnet, I. Diaz, C. Meric, E. Paoletti, J. Tartaglia, H. Salomon \& S. Plotkin: A prime-boost approach to HIV preventive vaccine using a recombinant canarypox virus expressing glycoprotein-160 (MN) followed by a recombinant glycoprotein 160 (MN/LAI). Aids Res Hum Retroviruses 11, 373-81 (1995)

153. Donnelly, J. J., J. B. Ulmer, J. W. Shiver \& M. A. Liu: DNA vaccines. Ann Rev Immunol 15, 617-48 (1997) 
154. Robinson, H. L. \& C. A. T. Torres: DNA vaccines. Semin Immunol 9, 271-83 (1996)

155. Pertmer, T. M., T. R. Roberts \& J. R. Haynes: Influenza virus nucleoprotein-specific immunoglobulin $G$ subclass and cytokine responses elicited by DNA vaccination are dependent on the route of vector DNA delivery. $J$ Virol 70, 6119-25 (1996)

156. Feltquate, D. M., S. Heaney, R. G. Webster \& H. L. Robinson: Different Th cell-types and antibody isotypes generated by saline and gene gun DNA immunization . $J$ Immunol 158, 2278-84 (1997)

157. Sundaram, P., W. Xiao \& J. L. Brandsma: Particlemediated delivery of recombinant expression vectors to rabbit skin induces high-titred polyclonal antisera (and circumvents purification of a protein immunogen). Nucl Acids Res 24, 13757 (1996)

158. Sundaram, P., R. E. Tigelaar \& J. L. Brandsma: Intracutaneous vaccination of rabbits with the cottontail rabbit papillomavirus (CRPV) L1 gene protects against virus challenge. Vaccine 15, 664-71 (1997)

159. Donnelly, J. J., D. Martinez, K. U. Jansen, R. W. Ellis, D. L. Montgomery \& M. A. Liu: Protection against papillomavirus with a polynucleotide vaccine. J Infect Dis 173, 314-20 (1996) 160. Krul, M. R. L., E. J. Tijhaar, J. A. F. W. Kleijne, A. M. Vanloon, M. G. Nivers, H. Schipper, L. Geerse, M. Vanderkolk, P. A. Steerenberg, F. R. Mooi \& W. Denotter: Induction of an antibody-response in mice against human papillomavirus (HPV) type-16 after immunization with HPV recombinant Salmonella strains. Cancer Immunol Immunother 43, 44-8 (1996)

161. Londono, L. P., S. Chatfield, R. W. Tindle, K. Herd, X. M. Gao., I. Frazer \& G. Dougan: Immunization of mice using Salmonella-typhimurium expressing human papillomavirus type16 E7 epitopes inserted into hepatitis-B virus core antigen. Vaccine 14, 545-52 (1996)

162. Nardelli-Haflinger, D., R. B. S. Roden, J. Benyacoub, R. Sahli, J. P. Kraehenbuhl, J. T. Schiller, P. Lachat, A. Potts \& P. De Grandi: Human papillomavirus type 16 virus-like particles expressed in attenuated Salmonella typhimurium elicit mucosal and systemic neutralizing antibodies in mice. Infect Immun 65, 3328-36 (1997)

163. Jensen, E. R., H. Shen, F. O. Wettstein, R. Ahmed \& J. F. Miller: Recombinant Listeria monocytogenes as a live vaccine vehicle and a probe for studying cell-mediated immunity. Immunol Rev 158, 147-57 (1997)

164. Jensen, E. R., R. Selvakumar, H. Shen, R. Ahmed, F. O. Wettstein \& J. F. Miller: Recombinant Listeria monocytogenes vaccination eliminates papillomavirus-induced tumors and prevents papilloma formation from viral DNA. J Virol 71, 846774 (1997)
165. Medaglini, D., C. M. Rush, P. Sestini \& G. Pozzi: Commensal bacteria as vectors for mucosal vaccines against sexually transmitted diseases:vaginal colonization with recombinant Streptococci induces local and systemic antibodies in mice. Vaccine 15, 1330-7 (1997)

166. Medaglini, D., M. R. Oggioni \& G. Pozzi: Vaginal immunization with recombinant gram-positive bacteria. Am J Reprod Immunol 39, 199-208 (1998)

167. Murphy, G., B. Tjoa, H. Ragde, G. Kenny \& A. Boynton: Phase I clinical trial: $\mathrm{T}$ cell therapy for prostate cancer using autologous dendritic cells pulsed with HLA-A0201-specific peptides. Prostate 29, 371-80 (1996)

168. Hsu, F. J., C. Benike, F. Fagnoni, T. M. Liles, D. Czerwinski, B. Taidi, E. G. Engleman \& R. Levy: Vaccination of patients with B-cell lymphoma using autologous antigenpulsed dendritic cells. Nat Med 2, 52-8 (1996)

169. Nestle, F. O., S. Alijagic, M. Gillet, Y. Sun, S. Grabbe, R. Dummer, G. Burg \& D. Schadendorf: Vaccination of melanoma patients with peptide- or tumor lysate-pulsed dendritic cells. Nat Med 4, 328-32 (1998)

170. Ossevoort, M. A., M. C. Feltkamp, K. J. H. van Veen, C. J. M. Melief \& W. M. Kast: Dendritic cells as carriers for a cytotoxic T-lymphocyte epitope-based peptide vaccine in protection against a human papillomavirus type 16-induced tumour. J Immunother 18, 86-94 (1995)

171. Mayordomo, J. L., T. Zorina, W. J. Storkus, L. Zitvogel, M. Garcia-Prats, A. B. DeLeo \& M. T. Lotze: Bone marrowderived dendritic cells serve as potent adjuvants for peptidebased antitumor vaccines. Stem Cells 15, 94-103 (1997)

172. De Bruijn, M. L. H., D. H. Schuurhuis, M. P. M. Vierboom, H. Vermeulen, K. A. J. de Cock, M. E. Ooms, M. E. Ressing, M. Toebes, K. L. M. C. Franken, J. W. Drijfhout, T. H. M. Ottenhoff, R. Offringa \& C. J. M. Melief: Immunization with human papillomavrius type 16 (HPV16) oncoproteinloaded dendritic cells as well as protein in adjuvant induces MHC class I-restricted protection to HPV16-induced tumor cells. Cancer Res 58, 724-31 (1998)

173. Tuting, T., T. Zorina, D. I. Ma, C. C. Wilson, C. M. De Cesare, A. B. De Leo, M. T. Lotze \& W. J. Storkus: Development of dendritic cell-based genetic vaccines for cancer. In: Dendritic Cells in Fundamental and Cinical Immunology. Eds: Ricciardi-Castangnloi, Plenum Press, New York, 511-8 (1997) 174. Van Oortmarssen, G. J., J. D. F. Habbema \& M. van Ballegooijen: Predicting mortality from cervical cancer after negative smear test results. B M J 305, 449-51 (1992)

175. Rozendaal, L., J. M. M. Walboomers \& J. C. Van der Linden: High risk human papillomavirus in cytomorphological normal smears has a high predictive value for development of severe dysplasia. Int J Cancer 68, 766-9 (1996) 
176. Melkert, P. J. W., E. Hopman, A. J. C. van den Brule, E. K. J. Risse, P. J. Van Diest, O. P. Bleker, T. Helmerhorst, M. E. I. Schipper, C. J. L. M. Meijer \& J. M. M. Walboomers: Prevalence of HPV in cytomorphologically normal smears as determined by the polymerase chain reaction is age-dependent. Int J Cancer 53, 919-23 (1993)

177. De Roda Husman, A. M., J. M. M. Walboomers, E. Hopman, O.P. Bleker, T.M. Helmerhorst, L. Rozendaal, F.J. Voorhorst \& C. J. L. M. Meijer: HPV prevalence in cytomorphologically normal cervical scrapes of pregnant women as determined by PCR: the age-related pattern. J. Med. Virol. 46, 97-102 (1995)

178. van Oortmarssen, G. J. \& J. D. F. Habbema: Epidemiological evidence for age-dependent regression of preinvasive cervical cancer. Br J Cancer 64, 559-64 (1991)

179.Lambert, H. E. \& P. R. Blake: Gynaecological Oncology. Oxford University Press, Oxford, (1992)

180. Luesley, D. M., J. Cullimore, C. W. Redman, F. G. Lawton, J. M. Emens, T. P. Rollason, D. R. Williams \& E. J. Buxton: Loop diathermy excision of the cervical transformation zone in patients with abnormal cervical smears. B M J 30, 16903 (1990)

181. Flannelly, G., H. Langhan, L. Jandial, E. Mann, M. Campbell \& H. Kitchener: A study of treatment failures following large loop excision of the transformation zone for the treatment of cervical intraepithelial neoplasia. $\mathrm{Br} J$ Obstet Gynaecol 104, 718-22 (1997)

182. Foster, C. A., K. S. Hall \& L. H. Smith: Detection of neutralising antibodies to papillomaviruses: Application for vaccine study. Papillomavirus Rep 8, 127-33 (1997)

183. Smith, L. H., C. Foster, M. E. Hitchcock, G. S. Leiserowitz, K. Hall, R. Isseroff, N. D. Christensen \& J. W. Kreider: Titration of HPV-11 infectivity and antibody neutralization can be measured in vitro. J Invest Dermatol 105, 438-44 (1995)

184. Bonnez, W., C. Darin, C. Borkhuis, K. M. Jensen, R. C. Reichman \& R. C. Rose: Isolation and propagation of human papillomavirus type 16 in human xenografts implanted in the severe combined immunodeficiency mouse. J Virol 72, 5256-61 (1998)

185. White, W. I., S. D. Wilson, W. Bonnez, R. C. Rose, S. Koenig \& J. A. Suzich: In vitro infection and type-restricted antibody-mediated neutralisation of authentic human papillomavirus type 16. J Virol 72, 959-64 (1998)

186. Roden, R. B., H. L. Greenstone, R. Kirnbauer, F. P. Booy, J. Jessie, D. R. Lowy \& J. T. Schiller: In vitro generation and type-specific neutralization of a human papillomavirus type 16 virion pseudotype. J Virol 70, 5875-83 (1996)
187. Unckell, F., R. E. Streek \& M. Sapp: Generation and neutralization of a human papillomavirus type 16 virion pseudotype. J Virol 71, 2934-9 (1997)

188. McMichael, A. J. \& C. A. O'Callaghan: A new look at T cells. J Exp Med 18, 1367-71 (1998)

189. Lalvani, A., R. Brookes, S. Hambleton, W. J. Britton, A. V. S. Hill \& A. J. McMichael: Rapid effector function in CD8+ memory cells. J Exp Med 186, 859-65 (1997)

190. Keating, P. J., F. V. Cromme, M. Duggan-Keen, P. J. F. Snijders, J. M. M. Walboomers, R. D. Hunter, P. A. Dyer \& P. L. Stern: Frequency of down-regulation of individual HLA-A and -B alleles in cervical carcinomas in relation to TAP-1 expression. Br J Cancer 72, 405-11 (1995)

191. Glew, S. S., M. Duggan-Keen, T. Cabrera \& P. L. Stern: HLA class II antigen expression in human papillomavirusassociated cervical cancer. Cancer Res 52, 4009-16 (1992)

192. Garrido, F., F. Ruiz-Cabello, T. Cabrera, J. J. Perez-Villar, M. Lopez-Botet, M. Duggan-Keen \& P. L. Stern: Implications for immunosurveillance of altered HLA class I phenotypes in human tumors. Immunol Today 18, 89-95 (1997)

193. Hilders, C. G. J. M., I. M. Munoz, Y. Nooyebn \& G. J. Fleuren: Altered HLA expression by metastatic cervicalcarcinoma cells as a factor in impaired immune surveillance. Gynecol Oncol 57, 366-75 (1995)

194. Bontkes, H. J., J. M. M. Walboomers, C. J. L. M. Meijer, T. J. M. Helmerhorst \& P. L. Stern: Specific HLA class I downregulation is an early event in cervical dysplasia associated with clinical progression. Lancet 351, 187-8 (1998)

195. Bartholomew, J. S., S. Glenville, S. Sarkar, D. J. Burt, M. A. Stanley, F. Ruiz-Cabello, J. Chenggang, F. Garrido \& P. L. Stern: Integration of high risk HPV DNA is linked to the downregulation of HLA class I antigens by glucocorticoid hormones in cervical cancer. Cancer Res 57, 937-42 (1997)

Key words: Human Papillomaviruses, Cervical Cancer, Viral Vaccines, Cancer Vaccines, Review, Cervical Intraepithelial Neoplasia, Immunotherapy

Send correspondence to: Dr Peter L. Stern, Paterson Institute for Cancer Research, Christie Hospital NHS Trust, Manchester M20 4BX , United Kingdom. Fax: 01614463109 Tel: 0161 4473127 E-mail: pstern@picr.man.ac.uk 